\title{
ローランにおける空間波の伝播誤差特性
}

\section{IV 空間波による位置の線並びに船位の精度}

\section{西 谷 芳 雄* \\ 東 海 林 修二**}

\section{Chracteristics of Loran Sky Wave Propagation Errors \\ IV. Errors of Loran Sky Wave Position Lines and Fixes \\ Y. Nishitani and S. Shoji}

\begin{abstract}
The accuracy of a Loran sky wave line of position depend chiefly upon the accuracy of matching and reading the signal on receiver-indicator, the accuracy of the sky wave correction and the geometrical factor of precision. We discussed the accuracy of matching sky wave by many observations and found that the influence on the accuracy of a position line is not so large compared with the other two effects. The distributions of the probable error of practical Loran sky wave position line about the several Loran pair at north pacific are calculated. The sky wave accuracy patterns are also shown. From these patterns, the navigator can see the accuracy of a Loran sky wave posision line at once.
\end{abstract}

\section{1. 緒 置}

空間波によるロラン位置の線の誤差の主な原因は時間差測定值の䛊差と幾何学的誤 差 である が，時間観測定值の誤差は伝播誤差すなわち空間波修正值の誤差と波形の重稀せや時閒差指示 の誤差すなわち観測誤差に分けられる。このうち観測誤差については，注意梁く測定すれば $3 \mu S$ をとえることはあるまいといわれている゙が，更に具体的にどの程度であるかを検討することは 重要なととである。

空間波修正值の誤差 ${ }^{2)}$ 及び幾何学的䛊差 ${ }^{3)}$ は受信地と発信局との相対的位置関係がわかれば計 算するととができる。しかし航海中に航海士官が計算することは相当面倒であるから，実際には 全く求められていないようである。從つて実際のロラン局に対する空間波による位置の線の精度 を計算して，わかりやすい表や等精度曲線を作つておけげ，実際の航海上に非常に便利であると 考えられる。

\section{2. 観 測上の誤差}

空間波を用いて位置の線を求める場合，その測定值に含まれる誤差は空間波伝播誤差（空間波

* 海技大学校

***日本油槽船株式会社 
修正值の誤差）と観測上の誤差に分けるととができる。空間波任播による中央誤差を $\Delta x$ ，観測 上の誤差 (中央誤差) を $\Delta y$ とすると, 測定值の中央誤差 $\Delta T$ は,

$$
\Delta T=\sqrt{\Delta x^{2}+\Delta y^{2}}
$$

伝播誤差 $\Delta x$ は次の式によつて求めることができる。 ${ }^{2)}$

$$
\Delta x=K \sqrt{\Delta x_{m}^{2}+\Delta x_{s}^{2}+\Delta x_{s y n c}^{2}}
$$

但し $\Delta x_{m}$ は主局から来る空間波の地表波に対するおくれの中央䛊差， $\Delta x_{s}$ は従局に対する䛊 差， $\Delta x_{s y n c}$ は同期䛊差である。またKは基線の長さに関係する定数で，基線の長さを $\beta(\mu s)$ とすると，

$$
K=0.21+0.000075 \beta
$$

$\Delta x_{m}$ 及び $\Delta x_{s}$ は何れも次の式で求めることができる。

$$
\Delta x_{m}=3.5+0.2\left(8-10^{-3} t\right)+1.8 \times 10^{-5}\left(8-10^{-3} \cdot t\right)^{7}
$$

但し $t$ は $\mu s$ で表わした受信地と主局との距離である。 $\Delta x_{s}$ も(4)と同じ式から求められる。(2)， (3)及び(4)式から伝播誤差 $\Delta x$ が求められる。

受信地を一定場所に固定して多数の測定を行えば，測定值の中央誤差 $\Delta T か ゙$ 判明する。そうす ると(1)式から観測上の誤差 $\Delta y$ を推定できる。

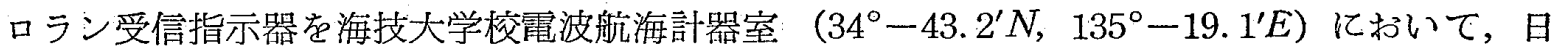
本近海のロラン局 $(2 H 0,2 H 3,2 H 4,2 H 5,2 S 1$ 及び $2 S 2)$ からの空間波（1-hop-E波）の 時間差を測定した。镍測值の中央誤差 $\Delta T$ は次の式から求められる。

$$
\Delta T=0.6745 \sqrt{\frac{\sum(T-\bar{T})^{2}}{N-1}}
$$

但し $N$ は観測総数， $T$ は測定時間差， $\bar{T}$ は測定值の算術平均である。この場合は測定場所が極め て明確に定つているから，電離艘の高さが標準状態である場合の空間波による時間差 (Expected

\begin{tabular}{|c|c|c|c|c|c|}
\hline & $\begin{array}{c}\text { 主局よりの距離 } \\
t_{m}(\mu s)\end{array}$ & $\begin{array}{c}\text { 従局上りの距離 } \\
t_{s}(\mu s)\end{array}$ & $\mid \begin{array}{c}\text { 測定值の中央誤差 } \\
\Delta T(\mu s)\end{array}$ & $\begin{array}{c}\text { 伝 播 誤 差 } \\
\Delta x(\mu s)\end{array}$ & $\begin{array}{c}\text { 観 測 䛊 差 } \\
\Delta y(\mu s)\end{array}$ \\
\hline $2 H 0$ & 1626 & 2857 & 4. 12 & 4. 29 & - \\
\hline $2 H 3$ & 2022 & 1874 & 4. 82 & 4.55 & 1.24 \\
\hline $2 H 4$ & 2022 & 3865 & 4. 49 & 3.87 & 2. 68 \\
\hline $2 H 5$ & 4149 & 3865 & 3. 48 & 3.59 & - \\
\hline $2 S 1$ & 2641 & 4298 & 2.95 & 2.73 & 1. 12 \\
\hline $2 S 2$ & 2641 & 1701 & 3.78 & 4. 22 & - \\
\hline
\end{tabular}
sky wave reading) がロラン・テーブルまたはロラン・チャートより求められるので，Tとして このような值をとるととにした。また測定実験は通常航海士が船舶において実際に測定する場合 とほぼ同程度の注意深さをもつて行われたものである。表 1 にはこのようにして測定した測定值

表 1 空間波による時間差測定差

に対する中央䛊差 $\Delta T$ 及び(2)，(3)，(4)式によつて計算された伝播誤差 $\Delta x$ を示す。但し同期誤差 $\Delta x_{\text {sync }}$ は $0.5 \mu s$ であるとした。測定值の中央誤差は先の(1) 式に示したように 観測誤差及び伝 
播誤差の 2 乗の和の平方根になる筈であるが，表 1 をみると測定值の中央誤差が伝播誤差よりも かえつて小さい場合がある。これは，伝播誤差を先の(2)式で評価すれば，観測誤差は全く問題に する必要がないととを表わしている。すなわちてのような場合は $\Delta y=0$ と考えてもよいととを 意味する。しかし測定值の愦差が伝播誤差よりも大きい場合も勿論ある。この場合は(1)式より観 測誤差を求めることができる。その值が表 1 の最後の項に示されている。観測誤差 (中央誤差)の 測平均值は $0.84 \mu s$ となるから，95\%䛊差で表わせば約 $2.4 \mu s$ となる。従つて文献に示されてい

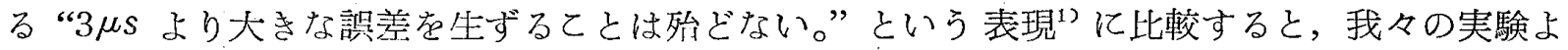
り得られた観測精度の方がわずかに良好である。ロラン受信指示器の調整並びに指示精度が普通 $1 \mu \mathrm{s}$ 以内であり，波形の重ね合せの精度も $1 \mu \mathrm{s}$ 以内であるととを考えると，空間波の観測精度 は若干恶くなる程度である。しかも測定值の誤差はそれぞれの誤差の 2 乗の和の平方根であるか ら，観測誤差の影響は更に小さいととが表1からわかるであろう。

この測定実験は発信局より測定地までの距離が比較的近い場合であるから，フエーデイングの 影響が大きく，観測誤差も割合に大きい等である。しかし一方においては，伝播誤差も割合に大 きいので, 観測誤差の影響はかえつて小さいかも知れない。基線の長さが300浬で，主,従局から 1300浬はなれた場所においては，伝播誤差は $1.74 \mu \mathrm{s}$ となる。観測誤差を $0.84 \mu s$ とすれば，測 定值の誤差は $1.93 \mu \mathrm{s}$ となり，その差はわずかに $0.19 \mu \mathrm{s}$ にずない。従つて位置の線の誤差を 評価する場合には，伝播誤差のみをもつて近似的に測定值の愼差と考光てもよいと結論すること ができる。

\section{3. 空間波によるロラン位置の線の精定}

空間波による位置の線の誤差 $\Delta s$ （浬）は，

$$
\Delta s=0.0809 \cdot \Delta T \cdot \operatorname{cosec} \frac{1}{2} \psi
$$

但しけは誤差を求めようとする地点から主従局をみた角度である。この角度は計算によつても求 めるてとができる。また 0.0809 $\operatorname{cosec} \frac{1}{2} \psi$ はいわゆる幾何学的誤差であるから，ロラン位置の線 の密度である。従つてロラン・テーブルやロラン・チヤートから簡単に求めるととができる。

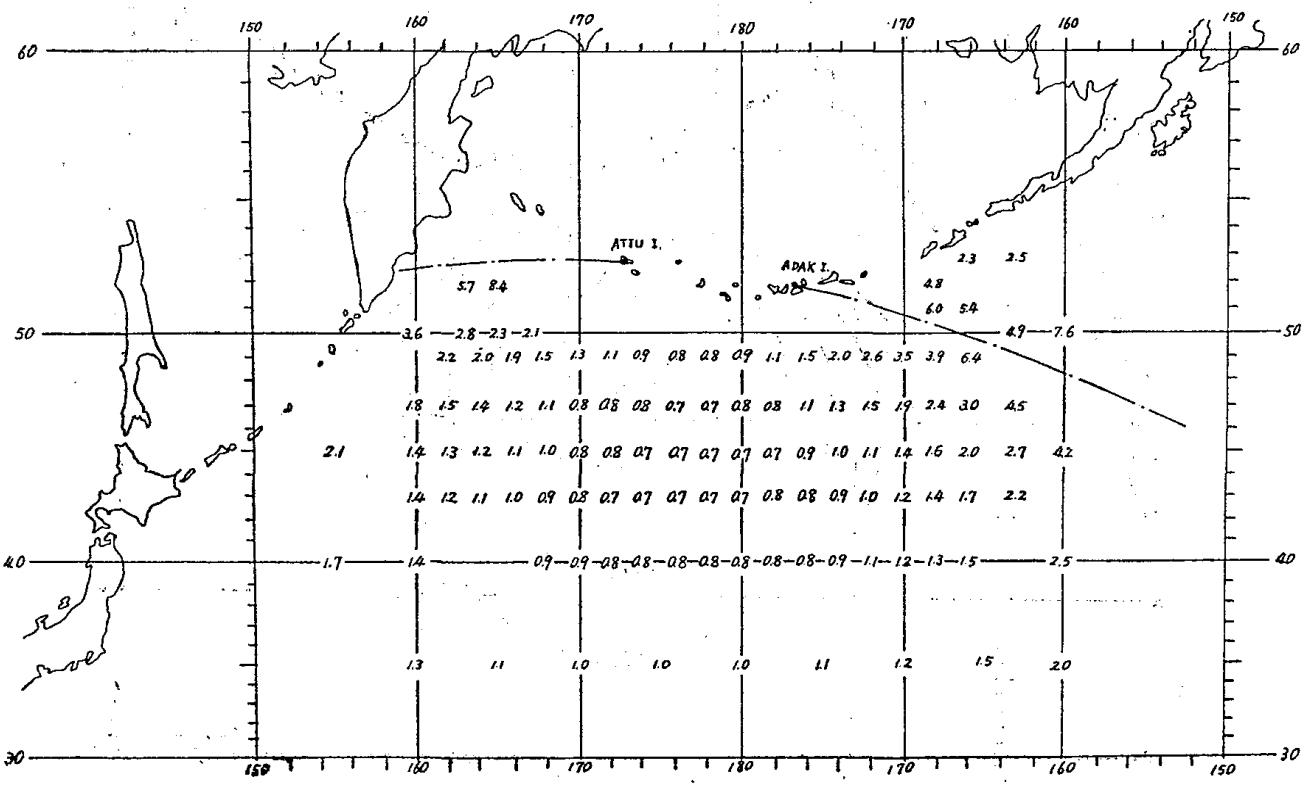

表 2 ，空間波によるロラン位置の線の精度，1L2。(50\%誤差, 単位一浬); 
$\Delta T$ は空間波による時間差測定值の精度であるが，先にのべたように近似的には伀播誤差とみる ことができる。従つて $\Delta T$ はその地点と主，従局との距離がわかれば計算するととができる。 わが国から北米への航海に当つてよく用いられるロラン局（アリユーシャンー $1 L 2,1 L 3)$ に ついて計算した。但しての場合も $\Delta x_{s y n c}=0.5 \mu \mathrm{s}$ とした。表 2 には $50 \%$ 䛊差で表わした $1 L 2 に$

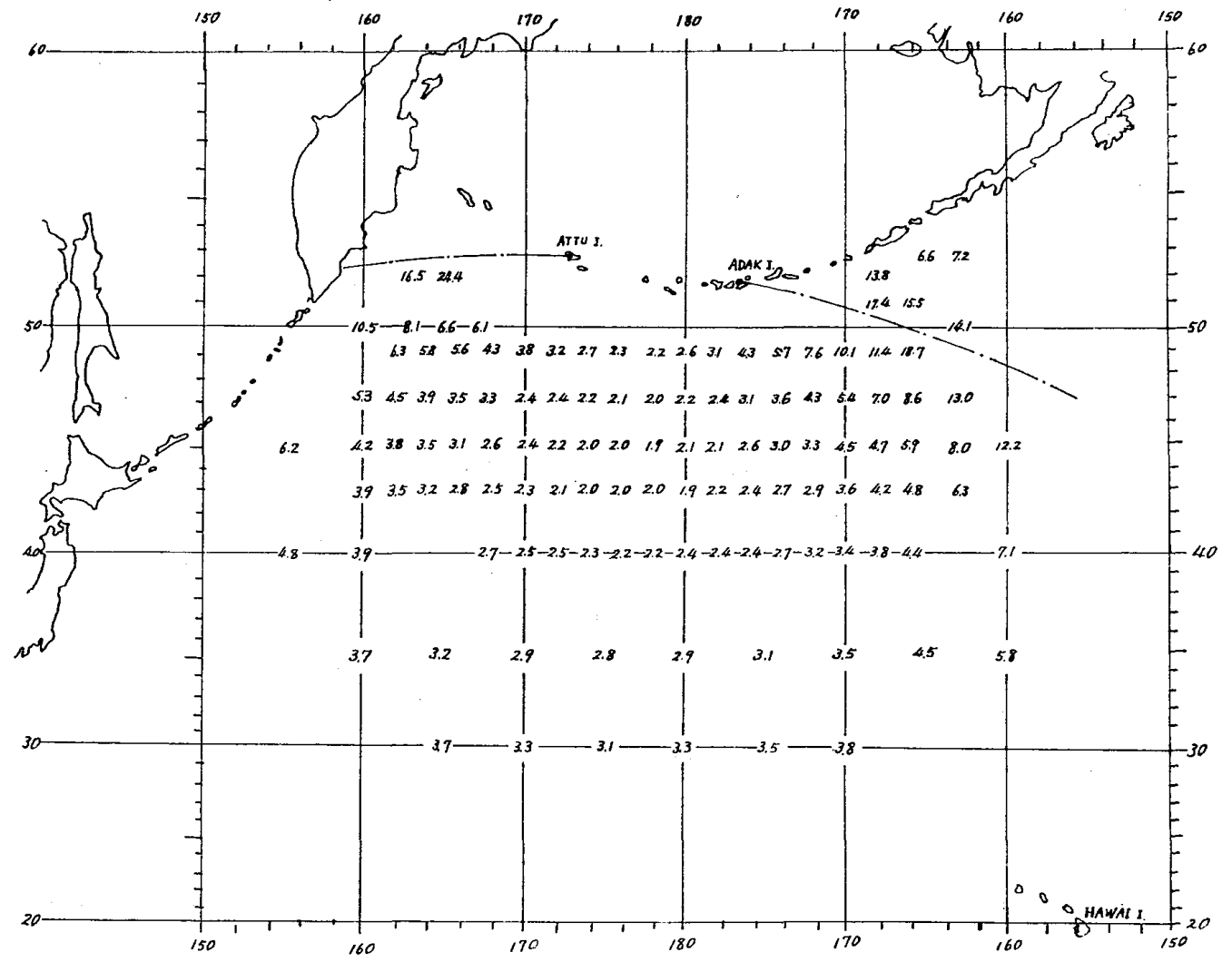

表 3 空間波によるロラン位置の線の精度， $1 L 2$. (95\%誤差，単位一浬）

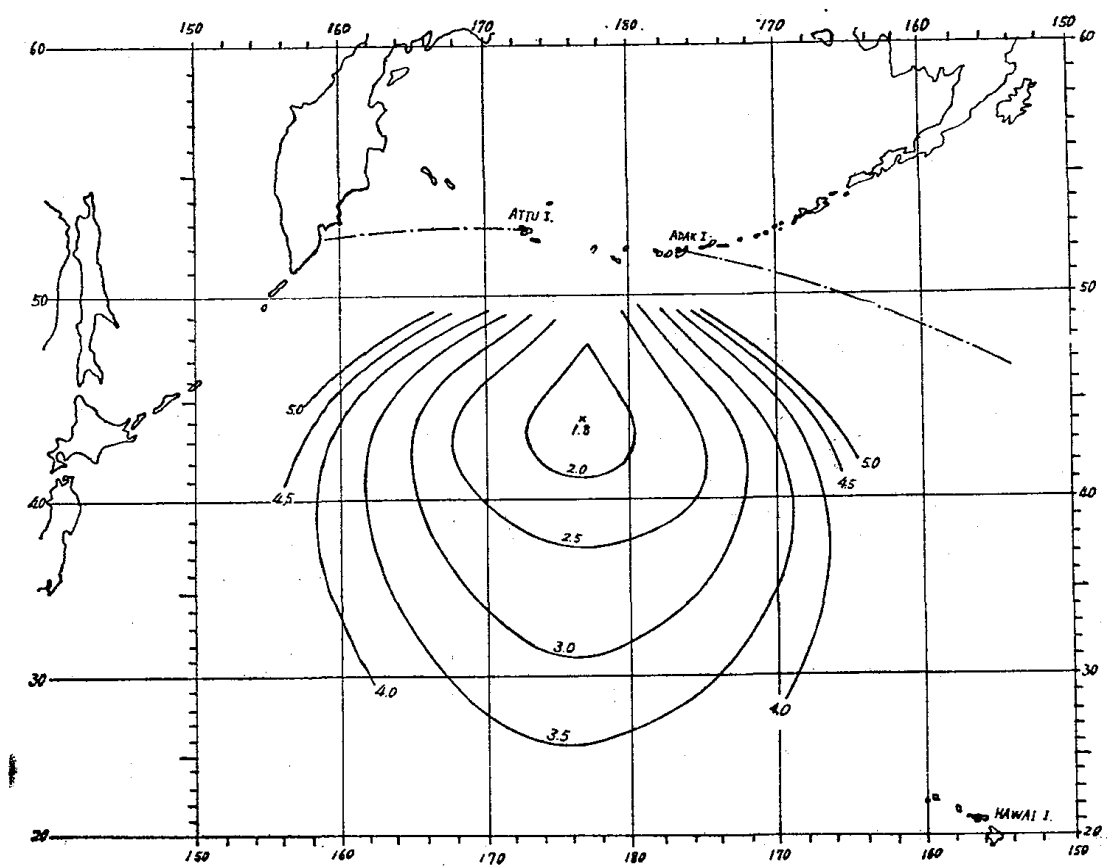

図 1 空間波によるロラン位置の線の精度曲線，1L2．（95\%誤差；単位一-浬） 
対する位置の線の誤差が示されている。航海者はこの表よりある地点における位置の線の中央誤 差を直ちに知ることができる。表 3 はこれを $95 \%$ 誤差で表わしたものである。図 1 は更に等精度 曲線 (95\%誤差) を示すものである。基線の垂直 2 等分線附近では精度の変化がゆるやかである ととがわかる。

表 4, 表 5 及び図 2 は $1 L 3$ 亿対する同上の精度を示している。以上の表や図からそれぞれの 空間波によるロラン位置の線の精度が直ちにわかるから，船位の精度を知る上に非常に便利にな つたわけである。

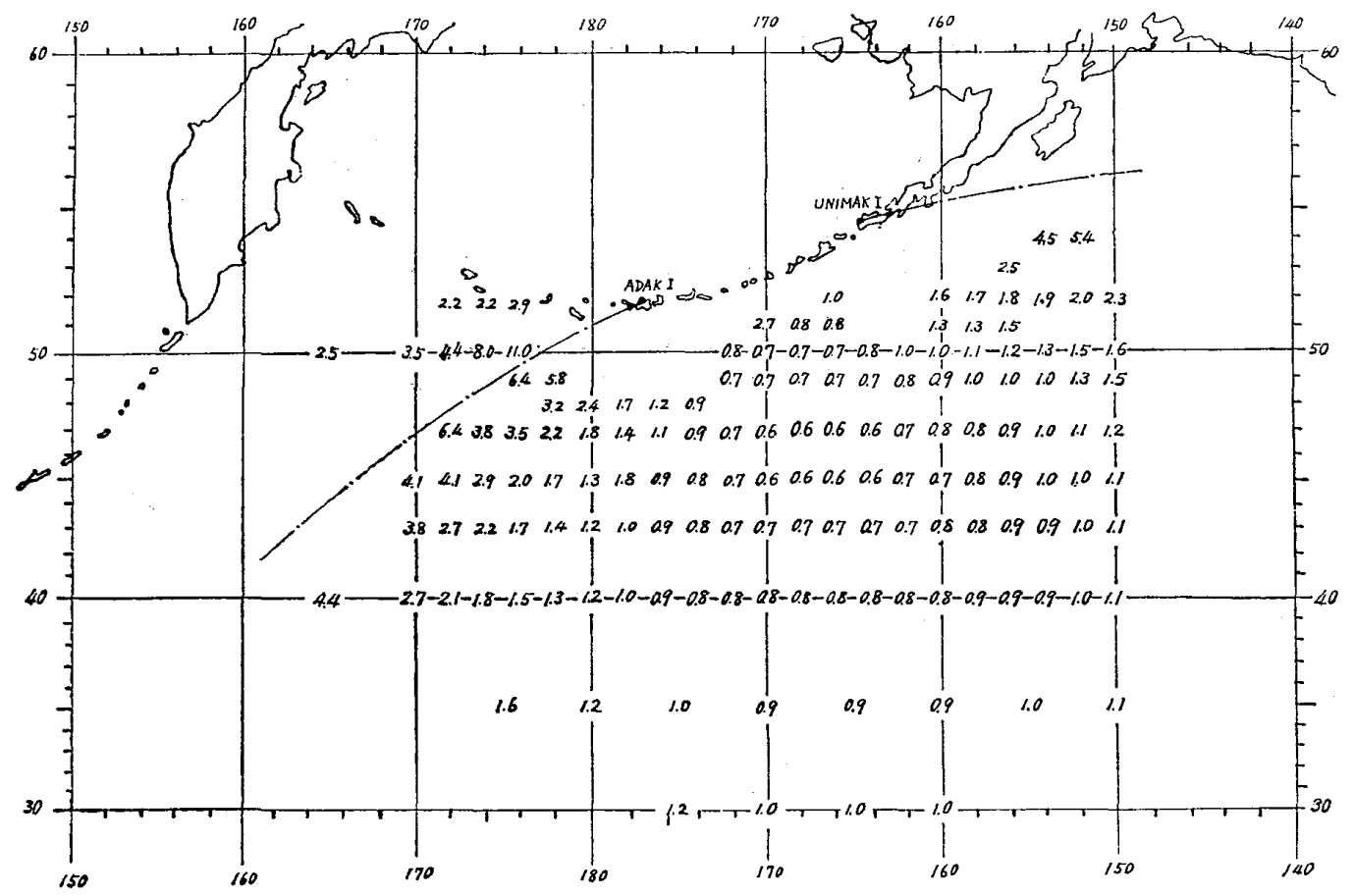

表 4 空間波によるロラン位置の線の精度，1L3.（50\%誤差，単位一浬）

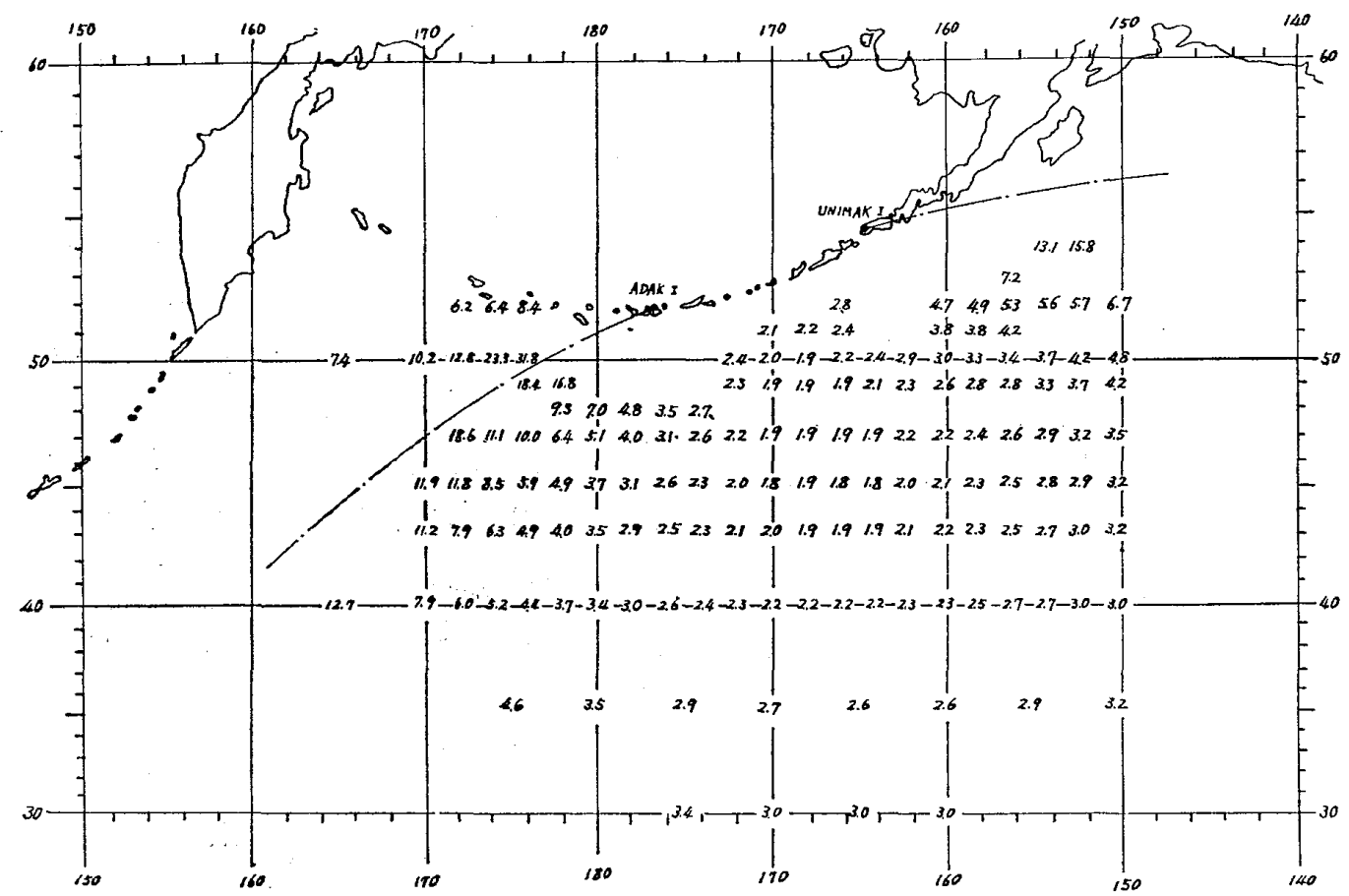

表 5 空間波によるロラン位置の線の精度, $1 L 3$. ( $95 \%$ 誤差, 単位一浬) 


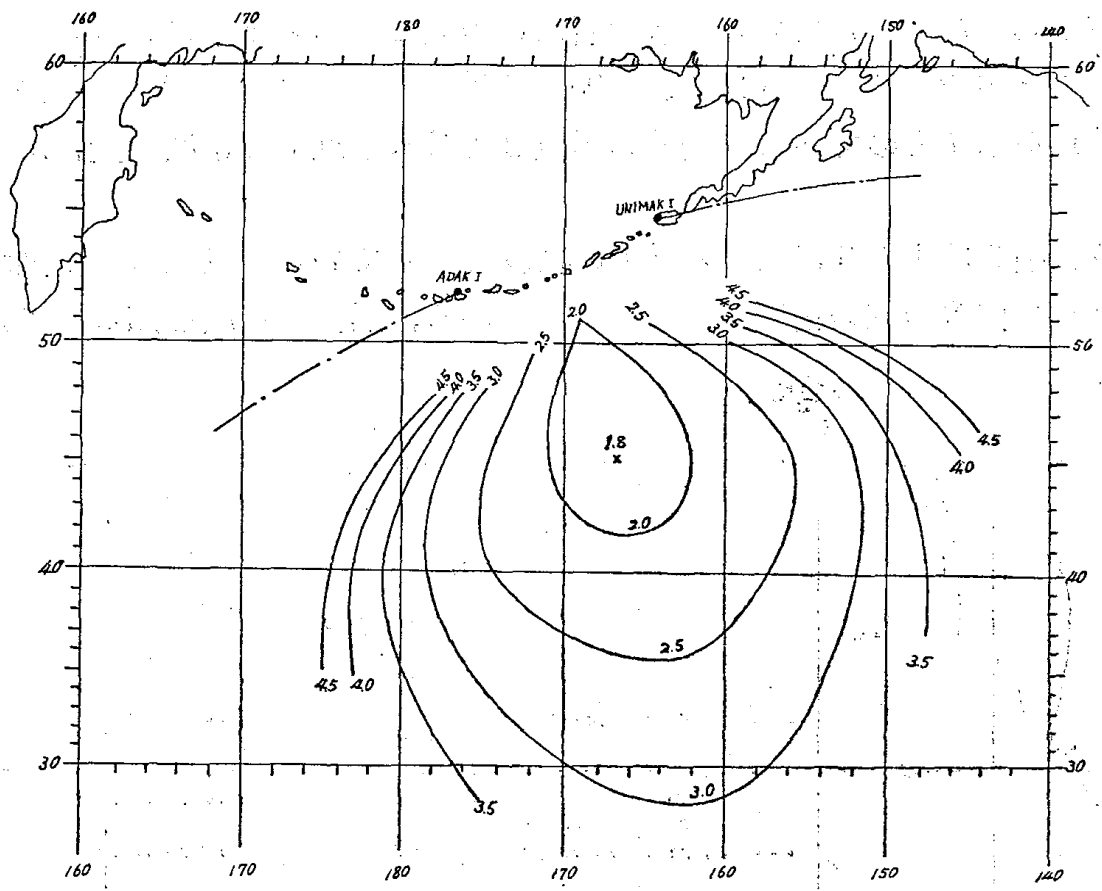

図 2 空間波によるロラン位置の線の精度曲線, 1 L3. (95\%誤差, 单位一浬)

\section{4. 空間波を用いた 2 本のロラン位置の線による船位の精度}

2 本の位置の線の交りによつて決定される船位の精度を考え客場合には，誤差棈円を考えるべ きであるが，実際に応用する場合には海図上に榇円を画くことは相当面倒であるのでとこでは 誤差界円をとるととにした。誤差界円の半径を゙とするど，

$$
r=\frac{2 \operatorname{cosec} \theta}{0.6745} \sqrt{\Delta s_{1}^{2}+\Delta s_{2}^{2}}
$$

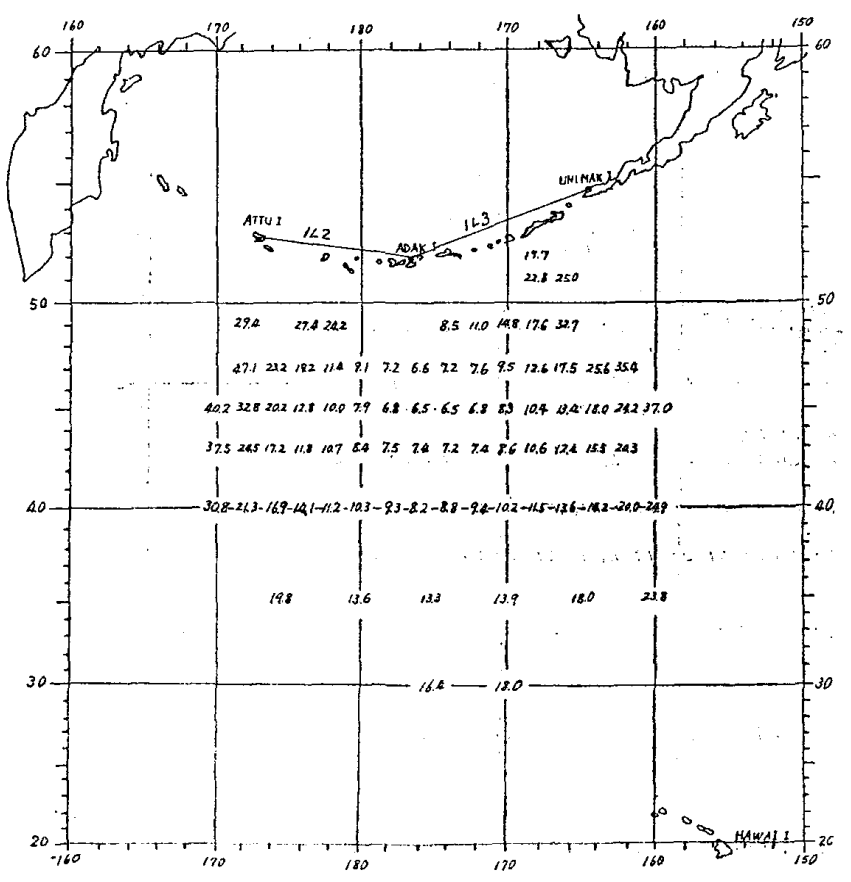

表 62 本のロラン空間波位置の線による船位誤差, $1 L 2$ と $1 L 3$ の組合せ. (95.5\%誤差界円の半径, 浬)

但し $\Delta s_{1}$ 及び $\Delta s_{2}$ はそれぞれの位置の線 の中央誤差， $\theta$ は 2 本の位置の線の交角で ある。このような半径 $r$ の内に船位の存 在する確率は $95.5 \%$ 以上である。

表 6 は空間波を用いた場合の $1 L 2$ ， $1 L 3 の$ 組品合せ纪よる船位誤差を上述の誤 差界円の半径（浬）で表わしている。図 3 在このよう船位誤差の等精度曲線であ る。乙れらの表 5 及び図 3 炭先の図 1 及び 図 2 と比較すると，それぞれの位置の線の 精度が割合に良好な場所でも，それらの交 点としての船位の精度が相当悪い場合が多 いととがわかる。乙れは $1 L 2$ 及び $1 L 3$ の 局配置に原因する所が大きいのである。

\section{5. 平均値を用いた場合の 誤差の改善}




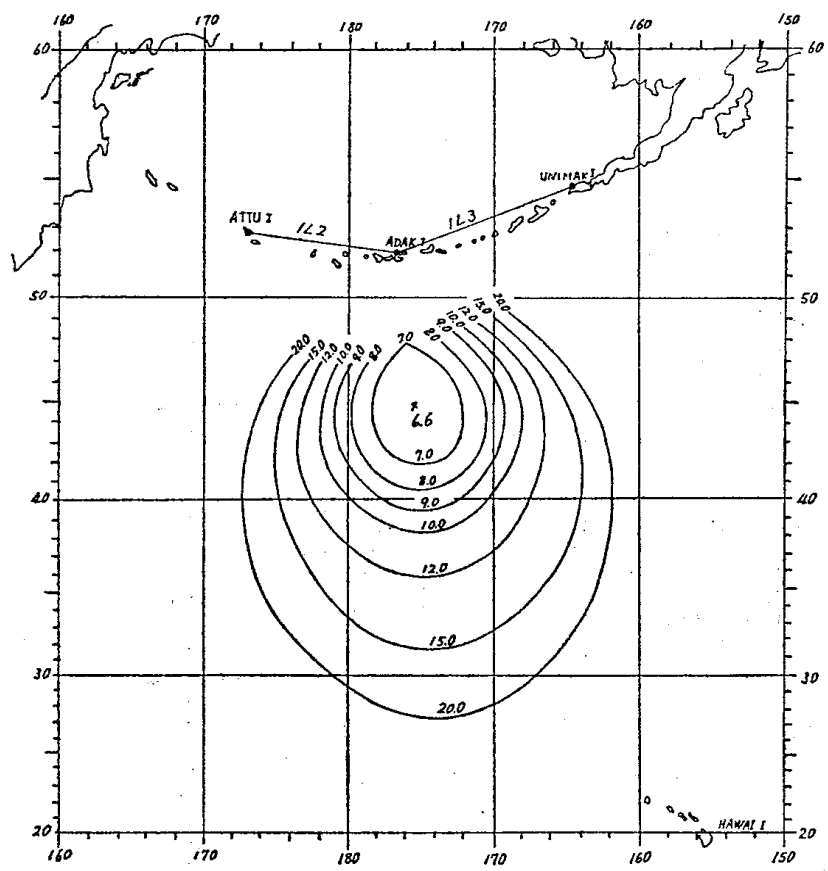

図 32 本のロラン空間波位置の線による船 位精度曲線, $1 L 2$ と $1 L 3$ の組合せ.

(95.5\%誤差界円の半径一浬)
以上で述べたようにそれぞれのロラン位 置の線の精度は，空間波を用いた場合でも 割合に良好であるが，その交点としての船 位には相当大きな愦差が含まれる領域が多 い。とれまでの結果は何れも 1 回の測定值 によつて位置の線を決定した場合のもので あるが，何回かの測定值の平均をとれば誈 差が相当改善される䈏である。

1 分間隔に5 回連続测定を行い，その算 術平均存もつて時間差測定值とすれば誤差 は約33\%改善されて，1回の測定值に対し て中央誤差が $67 \%$ 程度になるととを著者 の一人はすでに報告している5 。10 回の平 均をとれば愦差は更に多少減少するが，手 数がかささ割に政善は少い。5回の平均で あればあまり等力るかけずにとることがで きるから，てのような場合に位置の線及び 船位が如何程改善されるかを計算した。 5

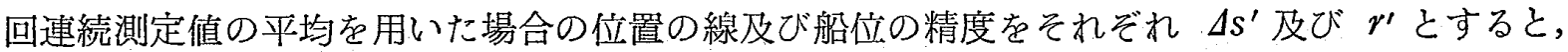

$$
\begin{aligned}
\Delta s^{\prime} & =0.67 \Delta s^{\prime} \\
r^{\prime} & =0.67 r
\end{aligned}
$$

図 4 ，図 5 はこのようにして計算したものである。これらを先の図 1 及び図 2 に比較すれば相 当精度か㳊善されているととがわかる。図 6 は $1 L 2$ と $1 L 3$ の組み合せによる船位の精度で，先 の図 3 に対応するものである。

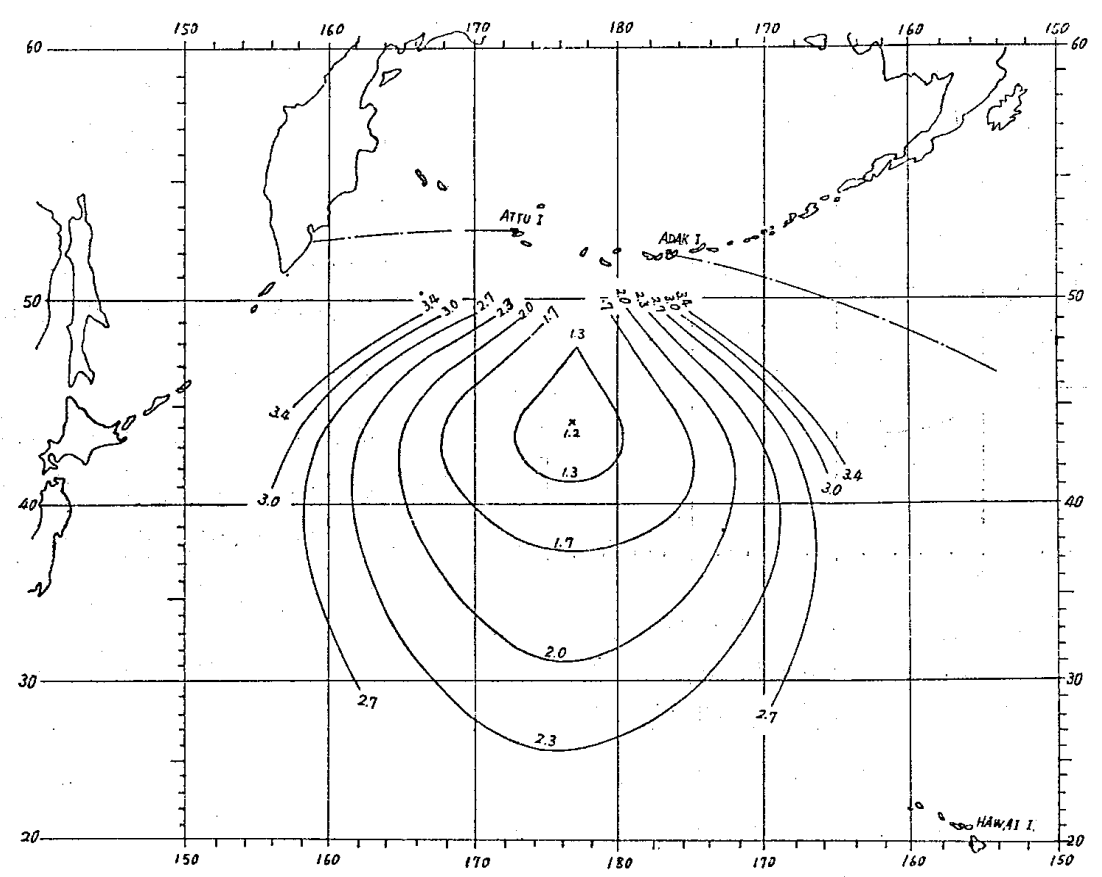

図 45 回の平均值によるロラン（空間波）位置の線の精度曲線，1L2（95\%誤差，単位一浬） 


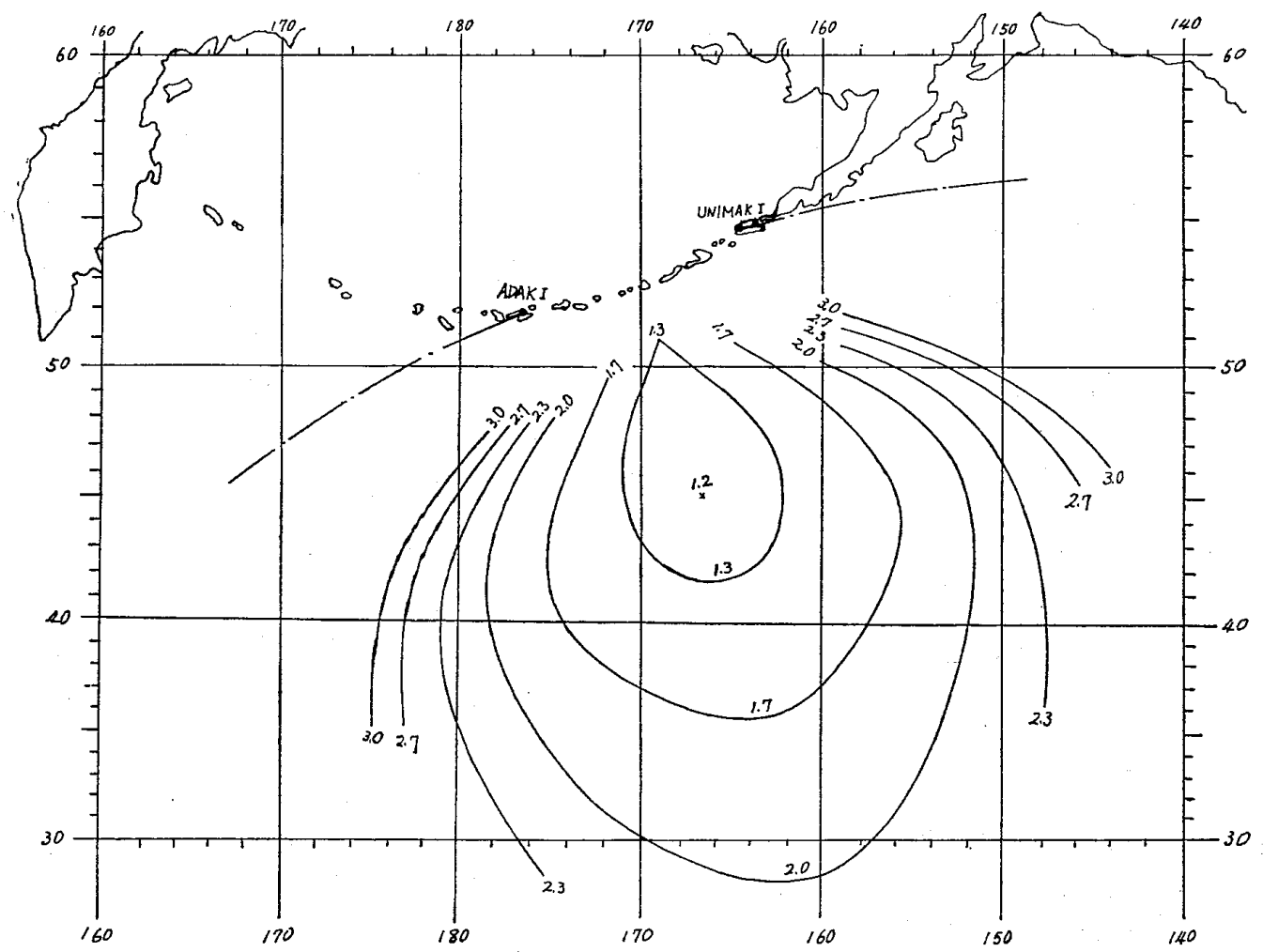

図 55 回の平均値によるロラン(空間波)位置の線の精度曲線， $1 L 3$. (95\%誤差，単位一浬)

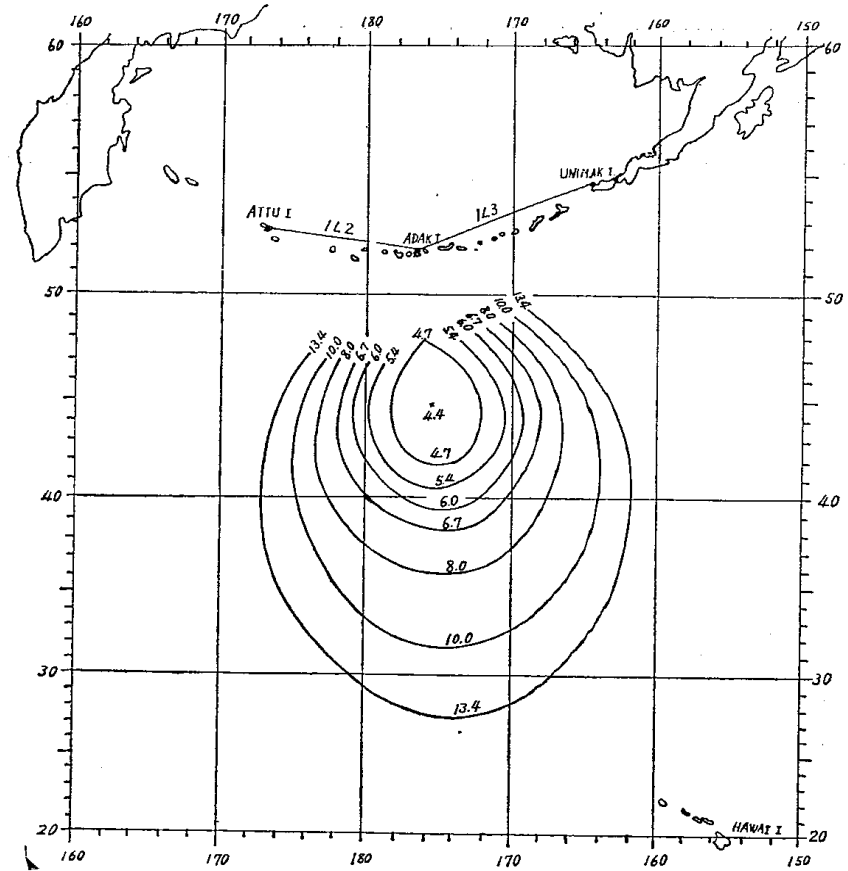

図 65 回の平均值を用いた場合の 2 本のロラン 空間波位置の線による船位精度曲線, $1 L 2$ $1 L 3$ の組合せ (95.5\%誤差界円の半径一浬)

\section{6. 結 論}

空間波によるロラン位置の線の誤差は時 間差測定值の誤差及び幾何学的精度によつ て決定される。時間差測定值の䛊差は伝播 誤差と測定技術上の誤差（観測誤差）とに 分けることができる。われわれは数多くの 実験によつて，推測䛊差は伝播誤差に比し て小さいから無視してもよいというととを 見出した。從つて空間波による位置の線の 精度は伝播誤差と幾何学的誤差とから計算 できるととがわかつだ。

わか帼から北米への航海に際してよく用 いられるロラン局（アリユーシャンー $1 L 2 ，$ 1L3）について，以上のような観点より空 間波による位置の線の誤差及び船位の精度 を計算し，実用に便利な表や図表を作製し た。航海者はこれらの表や図表より直ちに 位置の線や船位の精度を評価できるようになつたわけである。また数回の測定值の平均をとつた 場合の誤差の改善についても大体の目安が与えられたのである。

終りにのぞみ，ての研究を進めるに当つて種々有益な御検討をしていただいた海技大学校長谷 川助教授に対して深く感謝する次第である。 
參考文献

1) J. A. Pierce, A. A, Mckenzie and R. H. Woodward: Loran (1948) p. 89

2) 同上

p. 142

3）同上

p. 73

4) 酒井 進：天海文航学 (1957)

p. 322

5）市瀬，西谷，前田：ローランに於ける空間波の伝播誤差特性， II. 平均伹の意義

日本航海学会誌，第 17 号 (1957) p. 15 